\title{
PENDIDIK HARUS MELEK KOMPETENSI DALAM MENGHADAPI PENDIDIKAN ABAD KE-21
}

\author{
Maya Meilia, ${ }^{1}$ Murdiana ${ }^{2}$ \\ ${ }^{1}$ Sekolah Tinggi Ekonomi dan Bisnis Islam (STEBI) Lampung \\ Maya@stebilampung.ac.id \\ ${ }^{2}$ Sekolah Tinggi Ekonomi dan Bisnis Islam (STEBI) Lampung \\ Murhianadiana@gmail.com
}

\begin{abstract}
Education holds the most important role in improving the existence of the Human Resources produces quality, competitive in facing the Development of better education in the era of the 21st century. Therefore, efforts to improve the quality or the quality is sustainable. Teachers play a role important to apply their learning in the classroom, and therefore the need for teacher professional in carrying out their duties and responsibilities that may Literacy competence where the teacher in charge and implement the standard four competencies: competency pedagogical, personality, professional, and social, as well as teachers' literacy certification are required to always dynamically follow the development of science, technology, and information. As an educator, should the teacher have to learn a lifetime, build and develop themselves, so as to maintain its competence and professionalism as active in scientific studies such as PTK, active in the training and conduct further studies that could support its positions and professionalism of teachers in the profession. Real demonstration to do professional teachers for the challenges globalisasi among others master a variety of methods and instructional media to date, such as the method of group investigation is very suitable to be applied to materials that are difficult, and abstract though, that by raising the current issues that occurs in daily life-day so as to arouse the curiosity of learners, invites students to think critically and creatively in the face of economic problems as well as preparations for learners who are able to compete in the advancement of 21 st century education.
\end{abstract}

Keywords: Competence, Teacher Certification, Professionalism of Educators in the 21st Century, Methods Group Investigation.

\begin{abstract}
ABSTRAK
Pendidikan memegang peranan terpenting dalam meningkatkan eksistensi yang mengasilakan Sumber Daya Manusia berkualitas, kompetitif dalam menyongsong pembanguan pendidikan yang lebih baik di era abad ke-21. Oleh karena itu berbagai upaya peningkatan mutu atau kualitas dilakukan secara berkelanjutan. Guru memegang peranan terpenting untuk mejalankan proses pembelajaran di kalas, oleh karena itu diperlukannya guru yang profesional dalam melaksanakan tugas dan tanggung jawabnya yang dapat melak kompetensi dimana guru menguasi dan mengimplementasikan empat standar kompetensi: komptensi pedagogik, kepribadian, profesional, dan sosial, serta guru melek sertifikasi yang dituntut untuk selalu dinamis mengikuti perkembangan ilmu pengetahuan, teknologi, dan informasi. Sebagai pendidik, sudah seharusnya guru harus belajar seumur hidup, membangun dan mengembangkan dirinya, sehingga mampu mempertahankan kompetensi dan
\end{abstract}


profesionalitas yang dimilikinya seperti aktif dalam kajian ilmiah seperti PTK, aktif dalam pelatihan serta melakukan studi lanjut yang dapat menujang profesionalitas guru dalam jabatan dan profesinya, Pembuktian nyata yang harus dilakukan guru profesional untuk menghadapi tantangan globalisasi antara lain menguasai berbagai metode dan media pembelajaran mutakhir, seperti metode group investigation sangat cocok diterapkan untuk materi-materi yang sulit, dan abstrak sekalipun, yaitu dengan cara mengangkat topik aktual yang tejadi dalam kehidupan sehari-hari sehingga dapat membangkitkan rasa ingin tahu peserta didik, mengajak peserta didik berpikir kritis dan kreatif dalam menghadapi permasalahan ekonomi serta mempersipakan peserta didik yang mampu bersaing dalam kemajuan pendidikan abad ke-21.

\section{A. PENDAhULUAN}

Memasuki abad ke 21, sistem pendidikan nasional menghadapi tantangan yang sangat kompleks dalam menyiapkan kualitas sumber daya manusia yang kompeten serta mampu menghadapi tantangan pendidikan secara global, upaya yang tepat untuk dapat menyiapkan sumber daya manusia tersebut salah satu wadahnya adalah pendidikan. Dalam dunia pendidikan peran pendidik atau guru merupakan salah satu faktor yang sangat siginifikan dalam mencapai keberhasilan pendidikan. Guru merupakan bagian terpenting dalam proses belajar mengajar, karena gurulah yang paling dekat dengan siswa untuk dapat berinteraksi, berkomunikasi dalam proses pembelajaran berlangsung. Oleh sebab itu, dalam upaya peningkatan kualitas pendidikan di Indonesia peran guru tidak bisa dilepasakan dari eksistensi kemajuan pendidikan itu sendiri, yang tidak hanya dapat mentransformasikan knowledge, tetapi sebagai pendidik yang dapat melek kompetensi yang sesuai dengan perkembangan zaman dan kemajuan pendidikan.

Peranan guru di dalam proses pebelajaran merupakan jantungya pendidikan, apabila menginginkan SDM yang berkualitas tentunya didukung dengan peranan guru yang berkualitas pula, salah satunya guru harus melek dengan kompetensi, dimana kompetensi merupakan pondasi utama di dalam jiwa guru untuk dapat menjadi pendidik yang profesional,pendidik yang profesional mampu menghasilkan proses dan hasil pendidikan yang berkualitas dalam rangka mewujudkan manusia Indonesia yang cerdas dan kompetitif, sebagaimana diamanatkan oleh Undang-undang sistem pendidikan nasional serta guru yang profesional mengimpelentasikan filsafah yang ada pada setiap indikator-indikator standar kompetensi guru, karena guru tidak hanya memiliki selogan berstandar kompetensi saja, melainkan adanya nya bukti outentik yang nyata dari standar kompetensi yang dimilikinya. Hal yang paling menggelitik pikiran kita saat ini, sudahkah pendidik kita mampu bereksistensi terhadap peluang dan tantangan abad 21 ?

Menyadari kondisi diatas, pemerintah telah melakukan berbagai upaya untuk mengembangkan standar kompetensi dan sertifikasi guru, antara lain dengan disahkanya Undang-undang Republik Indonesia No 14 Tahun 2005 tentang guru dan dosen, disinilah peranan guru sebagai era reformasi pendidikan dapat mengembangkan soft skill, hard skill, dan life skill. Sehingga Diperlukan orang-orang yang memang benar benar-benar ahli di bidangnya, yang sesuai dengan kapasitas yang dimilikinya agar setiap orang dapat berperan secara maksimal, termasuk guru sebagai sebuah profesi yang menuntut kecakapan dan keahlian tersendiri. Profesionalisme tidak hanya karena faktor tuntutan dari perkembangan jaman, tetapi pada dasarnya juga merupakan suatu keharusan bagi setiap individu dalam kerangka perbaikan kualitas hidup manusia. Profesionalisme menuntut keseriusan dan kompetensi yang memadai, sehingga seseorang dianggap layak 
untuk melaksanakan sebuah tugas. Salah satu upaya untuk meningkatkan professionalisme guru adalah melalui sertifikasi sebagai sebuah proses ilmiah yang memerlukan pertanggung jawaban moral dan akademis dan mampu menerapkan standar kompetensi yang dimilikinya di dalam pendidikan dan kehidupan sehari-hari.

Menurut faktor lain yang harus dilakukan dalam mencapai profesionalisme guru adalah, perlunya perubahan paradigma dalam proses belajar mengajar. Anak didik tidak lagi ditempatkan sekedar sebagai obyek pembelajaran tetapi harus berperan dan diperankan sebagai subyek yang diarahkan untuk membelajaran pada student canter. Sang guru tidak lagi sebagai instruktur yang harus memposisikan dirinya lebih tinggi dari anak didik, tetapi lebih berperan sebagai fasilitator atau konsultator yang bersifat saling melengkapi. Dalam konteks ini, guru dituntut untuk mampu melaksanakan proses pembelajaran yang efektif, kreatif dan inovatif secara dinamis dalam suasana yang demokratis. Dengan demikian pendidikan yang mampu mendukung perkembangan di masa mendatang atau abad ke 21 adalah pendidikan yang mampu mengembangkan potensi peserta didik, sehingga yang bersangkutan mampu menghadapi dan memecahkan problem kehidupan yang dihadapinya, dengan memberikan dorongan untuk mencari tahu bukan pembelajaran yang memberi tahu, selanjutnya pendiikan harus menyentuh potensi nurani maupun potensi kompetensi peserta didik. Oleh sebab itu pembelajaran pada abad 21 harus didesain dengan berdasar pada pendektan belajar kontekstual konstruktivis, dimana pembelajaran yang memebiasakan siswa untuk membangun pengetahuannya sendiri berdasarkan konteks nyata yang dapat bermakna bagi dirinya sendiri, serta memebiasakan siswa untuk beraktivitas melakukan penelitian, pengamatan, eksperimen, observasi maupun melakukan aktivitas pengumpulan informasi dari berbagai sumber melalui kegiatan wawancara untuk memperoleh informasi, sehingga dari rangkaian pembelajaran ini diharapkan siswa dari awal sudah terbiasa untuk berpikir ilmiah, kritis, kreatif dan inovatif tanpa harus berpatokan pada penjelasan dan informasi dari guru saja.

Para pendidik Indonesia seharusnya peka dengan krisis ekonomi yang menunutut SDM yang mampu bersaing dan bersanding dalam pasar dunia kerja, jika tidak ingin tergantikan oleh pendidik asing. Oleh karena itu peranan guru sebagai salah satu profesi yang profesional di tuntut dapat melek dengan standar kompetensi yang mililikinya dengan memberikan bukti nyata perubahan proses pembalajaran yang banyak arah, aktif, bermakna, guru belajar sepanjang hayat, update dengan informasi yang terbaru, mempu menggunakan perangkat tegnologi dan cakap dalam menghadapi persaingan gelobal. Salah satu diantaranya kemampuan guru di dalam meggunakan perangkat pembelajaran seperti metode, pendekatan, model, teknik, alat, media dan sumber yang relevan dengan kehidupan sehari-hari siswa serta mengatur proses pembelajaran yang mutakhir mengarah pada pencarian atau saintis. Dengan demikian harus ditemukan cara-cara untuk membantu guru dalam mempersiapkan SDM tersebut dengan peranan pendidik yang melek dengan kompetensi yang dimilikinya serta penggunaan metode yang tepat dalam proses pembelajaran beralangsung.

Hal pokok yang akan dibahas dalam makalah ini ialah :

1. Kesiapan pendidik menghadapi pendidikan di abad ke-21.

2. Bagaimana metode group investigation dalam proses pembelajaran menjawab tantangan pendidikan abad ke-21.

\section{B. METODE PENELITIAN}

Metode penelitian ini menggunakan kajian teoritis yang mengambil beberapa teori yang mendukung kemudian di kaitan dengan hasil penelitian dan fenomena yang menjadi permasalahan, sehingga dapat memberikan gambaran atau alteratif menyelesaikan 
fenomena permasalahan yang terjadi seperti peluang dan tantangan kompetensi guru abad 21.

\section{HASIL DAN PEMBAHASAN}

\section{Standar Kompetensi Guru}

Era globalisasi yang ditandai dengan persaingan kualitas atau mutu, menuntut semua pihak dalam berbagai bidang dan sektor pembangunan untuk senantiasa meningkatkan kompetensinya, hal ini menujukan bahwa pentingnya setiap calon pendidik maupun pendidik memiliki pondasi sebagai suatu elemen dalam menjadikan pendidk yang profesional, serta merupakan suatu upaya dalam peningkatan kualitas pendidikan baik secara kuantitatif maupun kualitatif yang harus di asah dan dilakukan secara terus menerus, sehingga pendidikan dapat digunakan sebagai suatu wahana dalam membangun watak bangsa (nation character building). Oleh karena itu guru sebagai main person harus ditingkatkan kompetensinya untuk dapat mencapai tujuan pendidikan Nasional seutuhnya.

Pendidik yang telah mempunyai kulifikasi kompetesi harus bisa mengimplentasikan kompetensi yang dimilkinya dalam proses pembelajaran, menurut Murphy (1992) dalam Mulyasa, bahwa mutu pendidikan sangat ditentukan oleh gurunya, karena guru merupakan pemimpin pebelajaran, fasilitator dan sekaligus pusat inisiatif pembelajaran. Bersaman dengan hal itu bahwa peran guru di dalam proses pembelajaran merupakan komponen terpenting dalam menentukan keberhasilan sistem pendidikan secara keseluruhan, ${ }^{1}$ oleh karena itu upaya perbaikan apaun yang dilakukan untuk dapat meningkatkan kualitas pendidikan tidak akan memberikan sumbangan yang signifikan tanpa didukung oleh guru yang profesional dan berkualitas yang dapat memberikan bukti nyata dari standar kompetnsinya.

Kompetensi bagi beberapa profesi menjadi salah satu syarat penting dalam menjalankan kerangka dan tujuan organisasi. Masalah kompetensi itu menjadi penting, karena kompetensi menawarkan suatu kerangka kerja organisasi yang efektif dan efisien dalam mendayagunakan sumber daya yang terbatas. Dalam setiap pekerjaan maupun profesi, khususnya dalam bidang pendidikan. Tenaga pendidik terutama guru tentunya harus memiliki kompetensi yang sesuai dengan bidang dan tanggung jawabnya, karena sesorang guru yang memiliki kompetensi dalam profesinya akan dapat melaksanakan tugas-tugasnya dengan baik, tepat waktu dan sesuai dengan tujuan yang akan dicapai. Berkaitan dengan SDM yang berkualitas yang sesuai dengan harapan pendidkan di abad ke-21 guru menjadi tumpuan harapan dalam menciptkan dan memberdayakan kulaitas pendidikan, dimana selain beberapa kompetensi yang harus dimiliki, guru dituntut dapat melek angka (numerate), melek ilmu (science literacy), melek budaya (cultur literacy), serta memiliki kecerdasan spritual (spritual intelligence), kecerdasan emosi (emotional intelligence) dan kecerdasan intelektual (intellectual intelligence) yang baik.

Kata kompetensi berasal dari bahasa Inggris, "competence" yang artinya "wellqualified" atau "capabily". Dalam bahasa Indonesia diterjemahkan menjadi berkualifikasi atau mempunyai kualifikasi atau mampu atau mempunyai kemampuan (Webster, 2003). Kompetensi diartikan juga sebagai suatu skill pendidik. Mulyasa mendefiniskan kompetensi sebagai suatu kemampuan guru di dalam melaksanakan sesuatu yang diperoleh melaui pendidikan, serta menjukan performance dan rasional

\footnotetext{
${ }^{1}$ Mulyasa, Standar Kompetensi dan Sertifikasi Guru (Bandung: PT. Remaja Rosdakarya, 2013).
} 9. 
dalam menyelsaikan tugas-tugas pendidikan sesuai dengan arah dan tujuan yang nyata. ${ }^{2}$ Dengan demikian demikian kompetensi yang dimiliki oleh guru akan menunjukkan kualitas guru yang sesungguhnya. Kompetensi tersebut dapat diwujudkan dalam bentuk kemampuan guru secara personal, keilmuan, tegnologi, sosial, dan spiritual yang secara kaffah membentuk kompetensi standar profesi guru, yang mencakup penguasaan materi, pemahaman terhadap peserta didik pembelajaran yang mendidik, pengembangan pribadi dan profesionalisme. Seseorang yang memiliki kompetensi untuk jabatan tertentu berarti harus memiliki kemampuan yang betul-betul sesuai dengan tuntutan jabatan atau pekerjaan tersebut. Untuk menentukan kompetensi yang dimiliki sesuai dengan jabatan tersebut harus dilakukan analisis yang betul-betul menemukan kompetensi yang dituntut jabatan tersebut. Berdasarkan Peraturan Pemerintah RI Nomor 19 tahun 2005 Standar Nasional Pendidikan, Pasal 28 bahwa: Pendidik harus memiliki kualifikasi akademik dan kompetensi sebagai agen pembelajaran, sehat jasmani dan rohani, serta memiliki kemampuan untuk mewujudkan tujuan pendidikan nasional.

Pentingnya guru harus melek kompetensi ini dibuktikan oleh hasil penelitian Copriady (2014) menunjukan bahwa kompetensi guru merupakan suatu pilar di dalam mecapai keberhasilan pembelajaran, memberikan motivasi meraka untuk belajar dan memberikan umpan balik yang signifikan di dalam proses pembelajaran. Selanjutnya standar kompetensi mempunyai pengaruh yang positif terhadap prestasi belajar peserta didik, hasil penelitian Inayah, dkk.. ${ }^{3}$ Sedangkan menurut hasil penelitian Barinto (2012), standar kompetensi yang dimiliki oleh guru mempunyai hubungan yang signifikan dengan kinerja guru.

Sudah jelas bahwa standar kompetnsi harus dimiliki oleh setiap guru di dalam mencapai tujuan pembelajaran secara perofesional, oleh karena itu peranan guru untuk dapat menghasilkan dan menciptakan SDM yang berkualitas berawal dari guru itu sendiri, keberhasilan SDM atau peserta didik di dalam proses belajar tidak akan berhasil jika guru tidak memiliki standar kompetensi, serta kemampuan guru di dalam menghadapi tantangan global abad ke-21 tidak akan sanggup.

Kompetensi guru bukanlah suatu titik akhir dari suatu upaya melainkan suatu proses yang berkembang dan belajar sepanjang hayat. Kompetensi sebagai agen pembelajaran dalam mencapai tujuan, menurut Mulyasa, ${ }^{4}$ standar kompetensi yang harus dimiliki oleh guru terdiri dari 4 kompetensi dasar dan indikator-indikatornya yaitu pada tabel 1.1:

2 Mulyasa. 26.

3 Inayah, dkk., "Pengaruh Kompetensi Guru, Motivasi Belajar Siswa, dan Fasilitas Belajar Terhadap Prestasi Belajar Mata Pelajaran Ekonomi pada Siswa Kelas XII IPS SMA Negeri 1 Lasem Jawa Tengah Tahun Pelajaran 2011/2012," Jurnal Pendidikan Insan Mandiri, 1, 1 (2013).

${ }^{4}$ Mulyasa, Standar Kompetensi dan Sertifikasi Guru. 75-184. 


\section{Kompetensi Pedagogik}

Kompetensi pedagogik merupakan kemampuan guru didalam mengelola pembelajaran peserta didik yang meliputi pemahaman terhadap peserta didik, perencanaan dan pelaksanaan pembelajaran, evaluasi hasil belajar, dan pengembangan peserta didik untuk dapat mengaktualisasikan berbagai potensi yang dimilikinya. Hal ini tercantum di dalam Standar Nasional Pendidikan Pasal 28 ayat (3) butir a.

- Indikator Kompetensi Pedagogik

\begin{tabular}{|c|c|}
\hline $\begin{array}{l}\text { 1. Kemampuan } \\
\text { Mengelola } \\
\text { Pembelajaran }\end{array}$ & $\begin{array}{l}\text { Kemapuan guru didalam mengelola pembelajran merupakan } \\
\text { suatu kemapuan dimana guru melakuakan perencanaan, } \\
\text { yang menyakut penetapan tujuan, kompetensi, dan } \\
\text { memperkirakan cara untuk pencapaian. Pelaksanaan, } \\
\text { memberikan kepastian bahwa proses belajar mengajar telah } \\
\text { memiliki sumber daya manusia dan sarana prasarana yang } \\
\text { mendukung sehingga dapat membentuk kompetensi dan } \\
\text { pencapaian tujuan yang akan dicapai, serta pengorganisasian } \\
\text { dan kepemimpinan. Pengendalian, bertujuan untuk } \\
\text { menjamin kinerja yang dicapai dengan rencana dan tujuan } \\
\text { yang telah ditetapkan, serta pengambilan langkah-langkah } \\
\text { perbaikan apabila terdapat perbedaan yang signifikan atau } \\
\text { adanya keenjangan antara proses pembelajaran actual di } \\
\text { dalam kelas dengan yang telah dirancang sebelumnya. }\end{array}$ \\
\hline $\begin{array}{l}\text { 2. Pemahaman } \\
\text { terhadap peseta } \\
\text { didik }\end{array}$ & $\begin{array}{l}\text { Pemahaman terhadap peserta didik merupakan salah satu } \\
\text { indikator penting di dalam kompetensi pedagogik yang } \\
\text { terdapat beberapa aspek yang harus dipahami guru dari } \\
\text { peserta didik yaitu tingkat kecerdasan siswa, cacat fisik dan } \\
\text { perkembangan kognitif, karena kesemuanya ini dimiliki oleh } \\
\text { siswa dengan tingkatan yang berbeda-beda. }\end{array}$ \\
\hline $\begin{array}{l}\text { 3. Perencanaan } \\
\text { pembelajaran }\end{array}$ & $\begin{array}{l}\text { Perencanan pembelajaran mencakup beberapa yang harus } \\
\text { diperhatikan oleh guru yaitu, kemampuan guru untuk } \\
\text { mengidentifikasi kebutuhan siswa untuk mengetahui tingkat } \\
\text { kematangan dan kemampuan siswa di dalam proses } \\
\text { pembelajaran, serta perencanaan dalam ketelibatan siswa dan } \\
\text { memotivasi siswa agar agar kegiatan pembeajaran merupakan } \\
\text { bagian dari kehidupan mereka bukan sebagai beban, dan } \\
\text { membatu siswa untuk menyatakan apabila adanya hambatan } \\
\text { dalam upaya memenuhi kebutuhan belajr, baik yang secara } \\
\text { internal maupun external. Dan penyusunan program } \\
\text { pembelajaran, kemampuan guru didalam menyusun rencana } \\
\text { pelaksanaan pembelajaran(RPP) sesuai dengan kebutuhan } \\
\text { belajar siswa dan pembentukan kompetensi belajar siswa } \\
\text { yang mencakup SK, KD, materi, metode,teknik, media dan } \\
\text { sumber belajar, waktu belajar, dan daya dukung yang lainnya. }\end{array}$ \\
\hline $\begin{array}{l}\text { 4. Pelaksanaan } \\
\text { pembelajaran }\end{array}$ & $\begin{array}{l}\text { Bahawa untuk pelaksanaan pembelajaran guru hendaknya } \\
\text { merancang prmbelajaran seuia dengan kebutuhan siswa, }\end{array}$ \\
\hline
\end{tabular}




\begin{tabular}{|c|c|}
\hline $\begin{array}{l}\text { mendidik dan } \\
\text { dialogis }\end{array}$ & $\begin{array}{l}\text { dimana pemilihan metode yang tepat dan disesuikan dengan } \\
\text { tuntutan kurikulum yang berlaku, pengkondisian perangkat } \\
\text { pembelajaran yang dapat menunjang siswa untuk proses } \\
\text { pembelajaran yang efektif, serta mengkondisikan lingkungan, } \\
\text { sehingga diharapkan adanya perubahan prilaku siswa } \\
\text { sehingga terjadi interaksi pembelajran yang banyak arah } \\
\text { antara guru dan siswa (aktif). }\end{array}$ \\
\hline $\begin{array}{l}\text { 5. Pemanfaatan } \\
\text { teknologi } \\
\text { pembelajaran }\end{array}$ & $\begin{array}{l}\text { Pemanfaatan tegologi bagi guru merupakan salah satu aspek } \\
\text { indikator dari kompetensi pedagogic yang penting karena, } \\
\text { kemampuan guru untuk dapat memanfaatkan e-learning, agar } \\
\text { guru dapat mengembangkan pengetahuan, tegnologi, dan } \\
\text { sumber informasi untuk dapat menunjang proses mengajar } \\
\text { sehingga dapat memebtuk kompetensi siswa sesuai dengan } \\
\text { tujuan secara umum dan khusus. }\end{array}$ \\
\hline $\begin{array}{l}\text { 6. Evaluasi hasil } \\
\text { belajar }\end{array}$ & $\begin{array}{l}\text { Evaluasi hasil belajar dialakukan untuk mengetahui } \\
\text { perubahan prilaku dan oembetukan kompetensi siswa di } \\
\text { dalam mencapai hasil belajarnya, yang dapat dilakukan } \\
\text { dengan penilain kelas, tes kemampuan dasar, penilaian akhir } \\
\text { satuan pendidikan, dan sertifikasi, serta peilian suatu } \\
\text { program. Sehingga pentingnya evaluasi hasil belajar ini } \\
\text { dikuasai oleh guru sebagai tolak ukur keberhasilan guru di } \\
\text { dalam mengajar. }\end{array}$ \\
\hline $\begin{array}{l}\text { 7. Penge } \\
\text { pesert }\end{array}$ & $\begin{array}{l}\text { Pengembangan peserta didik diguanakan untuk } \\
\text { mengaktualisasikan berbagai potensi yang dimiliki oleh } \\
\text { siswa, pengembangan peseta didik ini dapat dilakukan oleh } \\
\text { guru melalui berbagai cara, yaitu melalui kegitan ekstra } \\
\text { kulikuler (eskul), pengayaan dan remedial, serta bimbingan } \\
\text { dan konseling (BK). }\end{array}$ \\
\hline \\
\hline \multicolumn{2}{|c|}{$\begin{array}{l}\text { Kompetensi keperibadian merupakan kemampuan keribadian yang mantap, stabil, } \\
\text { dewasa, arif, dan berwibawa, menjadi teladan bagi peserta didik, dan berakhlak } \\
\text { mulia, yang tercantum dalam Standar Nasional Pendidikan, pasal } 28 \text { ayat (3) butir } \\
\text { b. }\end{array}$} \\
\hline \multicolumn{2}{|c|}{ - Indikator kompetensi keperibadian } \\
\hline $\begin{array}{l}\text { 1. Keperibadian yang } \\
\text { mantap, stabil, dan } \\
\text { dewasa }\end{array}$ & $\begin{array}{l}\text { Kompetensi kepribadian diaman Guru mampu mengelola } \\
\text { pembelajaran yang membuktikan bahwa guru dihormati } \\
\text { oleh peserta didik, sehingga semua peserta didik selalu } \\
\text { memperhatikan guru dan berpartisipasi aktif dalam proses } \\
\text { pembelajaran. } \\
\text { Guru harus mempunyai kepribadian yang stabil diaman } \\
\text { guru harus bisa mengkontrol emosinya ketika dalam PBM. } \\
\text { Guru bertingkah laku sopan dalam berbicara, } \\
\text { berpenampilan, dan berbuat terhadap semua peserta didik, } \\
\text { orang tua, dan teman sejawat. }\end{array}$ \\
\hline $\begin{array}{l}\text { 2. Disiplin, arif dan } \\
\text { berwibawa }\end{array}$ & $\begin{array}{l}\text { Dalalam hal ini disiplin guru merupakan hal yang peting } \\
\text { karena menjadi suri tauladan bagi siswa, misalnya guru } \\
\text { harus mendisiplinkan peserta didik dengan kasih sayang, } \\
\text { terutama disiplin diri (self-discipline), tepat waktu, }\end{array}$ \\
\hline
\end{tabular}




\begin{tabular}{|l|l|}
\hline & $\begin{array}{l}\text { menanamkan rasa tanggung jawab atas tugas sebagai siswa, } \\
\text { tegas dalam mengendalikan sidiplin peserta didik,guru } \\
\text { harus menciptakan iklim pembelaharan yang kondusif, } \\
\text { yang dapat memodifikasi prilaku siswa. }\end{array}$ \\
\hline 3. Menjadi tauladan \\
bagi siswa & $\begin{array}{l}\text { Guru merupakan teladan bagi para siswa sehingga guru } \\
\text { harus bisa menempatkan kepribadaian yang arif, tidak } \\
\text { sombong, bertutur kata baik, menyadari kelebihan dan } \\
\text { kekuranggann, bisa menghargai pendapat orang lain . }\end{array}$ \\
Selanjutnya guru saling menghormati dan menghargai \\
teman sejawat sesuai dengan kondisi dan keberadaan \\
masing- masing.
\end{tabular}

3. Kompetensi Profesional

Kemampuan penguasaan materi pembelajaran secara luas dan mendalam yang memungkinkan dapat membimbing peserta didik untuk memenuhi standar kompetensi yang ditetapkan di dalam Standar Nasional Pendidikan, dan kompetensi ini tercantum dalam Standar Nasional Pendidikan, pasal 28 ayat (3) butir c.

- Indikator kompetensi profesional

Seorang guru harus memahami jenis-jenis materi pembelajaran yang akan disampaikan, baik dalam menjabarkan materi sesuai dengan standar kurikulum, untuk kepentingan tersebut guru harus mampu menentukan

1. Memahami jenismateri yang relevan dengan kebutuhan dan kemampuan jenis materi pembelajaran peserta didik baik secara validaitas materi, keberartian atau kepentingan materi yang disampikan sesuai dengan kebutuhan dan kemampuan peserta didik, relevansi atau tingkat kemampuan siswa artinya tingkat kesukaran materi, kemenarikan, dan kepuasan atau keberhasilan pembelajaran dari materi yang disampaikan.

2. Mengurutkan materi pembelajaran

Agar pembelajaran dapat dilakukan secara efektif dan menyenagkan, materi yang di sampaikan guru harus berurutan, serta dijelaskan mengenai batasan dan ruang 


\begin{tabular}{|c|c|}
\hline & $\begin{array}{l}\text { lingkupnya, hal yang dapat dilakukan oleh guru agar } \\
\text { penyampaian materi pembelajaran berurutan dengan } \\
\text { menyusun SKKD, menjabarkan SKKD kedalam indikator, } \\
\text { serta mengembangkan ruang lingkup dan urutan setiap } \\
\text { kompetensi untuk mencapai tujuan pembelajaran dan } \\
\text { membentuk kompetensi dasar. }\end{array}$ \\
\hline $\begin{array}{l}\text { 3. Mengorganisasikan } \\
\text { materi pembelajaran }\end{array}$ & $\begin{array}{l}\text { Kemampuan guru untuk mengorganisasikan bahan } \\
\text { pembelajaran dengan perencanaan, pelaksanaan dan } \\
\text { penilaian materi pembelajaran, dengan demikian, materi }\end{array}$ \\
\hline $\begin{array}{l}\text { 4. Mendayagunakan } \\
\text { sumber } \\
\text { pembelajaran }\end{array}$ & $\begin{array}{l}\text { Guru dituntut untuk mempelajari berbagai sumber, seperti } \\
\text { majalah, susrat kabar, dan internet, karena guru tidak hanya } \\
\text { mendayagunakan sumber-sumber yang ada di buku ajar } \\
\text { saja. }\end{array}$ \\
\hline $\begin{array}{l}\text { 5. Memilih dan } \\
\text { menetukan materi } \\
\text { pembelajaran }\end{array}$ & $\begin{array}{l}\text { Diamana guru harus dengan cermat, untuk memilih materi } \\
\text { yang sesuai dengan kebutuhan siswa di dalam kehidupan } \\
\text { sehari-hari (relevansi), selanjutnya kemampuan guru } \\
\text { didalam menentukan materi yang sesuai dengan SKKD dan } \\
\text { kepuasan siswa, kemenarikan siswa di dalam belajar. }\end{array}$ \\
\hline \multicolumn{2}{|l|}{ 4. Kompetensi Sosial } \\
\hline \multicolumn{2}{|c|}{$\begin{array}{l}\text { Kompetensi sosial merupakan kemampuan guru sebagai bagian dari masyarakat } \\
\text { untuk dapat berkomunikasi dan bergaul secara efektif dengan peserta didik, } \\
\text { sesama pendidik, tenaga kependidikan, orang tua atau wali murid dan masyarakat } \\
\text { sekitar, kompetensi sosial tercantum dalam Standar Nasional Pendidikan Pasal } 28 \\
\text { ayat (3) butir b. }\end{array}$} \\
\hline \multicolumn{2}{|c|}{ - Indikator Kompetensi Sosial } \\
\hline $\begin{array}{l}\text { 1. Berk } \\
\text { berg } \\
\text { efekt }\end{array}$ & $\begin{array}{l}\text { Kemampuan guru di dalam berkomunikasi dan bergaul } \\
\text { secara efektif, dengan peserta didik, sesama pendidik, } \\
\text { tenaga kependidikan, orang tua wali, dan masyarakat } \\
\text { sekitar, karena keperibadian masyarakat di tengah-tengah } \\
\text { masyarakat, dimana guru perlu memiliki kemampuan untuk } \\
\text { berbaur dengan masyarakat melalui kemampuannya, antara } \\
\text { lain : melalui kegiatan olah raga, keagamaan, dan } \\
\text { kepemudaan. } \\
\text { Kemudian guru harus memiliki kemampuan untuk bergaul } \\
\text { secara efektif dengan masyarakat, sehingga dapat diterima } \\
\text { dilingkungan masyarakat. }\end{array}$ \\
\hline $\begin{array}{l}\text { 2. Hubu } \\
\text { denga }\end{array}$ & $\begin{array}{l}\text { Sekolah berada ditengah-tengah masyarakat, dengan } \\
\text { demikian terdapat kerjasama dan saling membantu antara } \\
\text { sekolah dan masayarak sehingg saling berkesinambungan } \\
\text { untuk dapat mencapai tujuan pendidikan seutuhnya. }\end{array}$ \\
\hline $\begin{array}{l}\text { 3. Peran guru di } \\
\text { masyarakat }\end{array}$ & $\begin{array}{l}\text { Peranan guru di tengah masyarakat dapat membimbing } \\
\text { masyarakat dalam menghadapai kehidupan di masa yang } \\
\text { datang. } \\
\text { Guru diharapkan menjadi tokoh yang dapat ditiru di tengah } \\
\text { masyrakat dengan keperibadian yang arif, bijaksana dan } \\
\text { dapat memberikan solusi dengan permasalahan- } \\
\text { permasalahan yang ada. } \\
\text { Guru diharapkan mampu mendorong dan menunjang } \\
\text { kreativitas masyarakat. }\end{array}$ \\
\hline
\end{tabular}




\begin{tabular}{|l|l|}
\hline & $\begin{array}{l}\text { Guru mampu menjaga emosi dan perilaku yang kurang } \\
\text { baik. }\end{array}$ \\
\hline & $\begin{array}{l}\text { Dimana guru diharapkan mampu mendorong perubahan } \\
\text { dan toleransi serta tidak sekedar mencerdasakan peserta } \\
\text { didik akan tetapi mengembangkan keperibadian yang utuh, } \\
\text { berakhlak, dan berkarakter. } \\
\text { Guru mampu menjembatani pola berpikir siswa untuk dapat } \\
\text { mengarahkan pola berpkir siswa dimana yang positif sesuai } \\
\text { perubahan sosial } \\
\text { dengan perkembangan zaman dan teknologi. }\end{array}$ \\
\hline
\end{tabular}

\section{Sertifikasi Guru}

Pada hakekatnya standar kompetensi dan sertifikasi guru untuk mendapatkan guru yang baik dan profesional, yang memiliki kompetensi untuk melaksanakan fungsi dan tujuan sekolah khususnya, serta tujuan pendidikan pada umumnya sesuai dengan kebutuhan masyarakat dan tuntutan zaman. Dalam Undang-Undang RI Nomor 14 Tahun 2015 tentang Guru dan Dosen, dikemukakan bahwa sertifikasi merupakan proses pemberian sertifikat pendidik untuk guru dan dosen, yang ditujukan sebagai bukti formal pengakuan tenaga profesional yang telah lulus uji kompetensi. Sehingga dengan adanya sertifikasi yang diberikan oleh guru merupakan bukti nyata bahwa guru yang telah sertifikasi memiliki kualifikasi kompetensi untuk melaksanakan pelayanan pendidikan, mencapai tujuan pendidikan sesuai dengan sasaran dan mampu menghadapi era pendidikan gelobal. Sertifikasi guru merupakan pemenuhan kebutuhan untuk meningkatkan kompetensi profesional. Oleh karena itu, proses sertifikasi dipandang sebagai bagian esensial dalam upaya memperoleh sertifikat kompetensi sesuai dengan standar yang telah ditetapkan.

Sertifikasi guru merupakan upaya peningkatan mutu guru yang diikuti dengan peningkatan kesejahteraan guru, sehingga diharapkan dapat meningkatkan mutu pembelajaran dan mutu pendidikan di Indonesia secara berkelanjutan (Dediknas, 2008:1). Pendapat yang sama dikemukakan oleh Mulyasa, sertifikasi guru merupakan prosedur yang digunakan oleh pihak yang berwenang untuk memberikan jaminan tertulis bahwa seseorang telah memenuhi peryaratan kompetensi sebagai guru. Sehingga sertifikasi guru merupakan pemenuhan kebutuhan untuk meningkatkan kompetensi profesional. Lebih lanjut dikemukakan menurut Wibowo dalam Mulyasa mengungkapkan bahwa sertifikasi bertujuan untuk hal-hal sebagai berikut : 1) melindungi profesi pendidik dan tenaga kependidikan, 2) melindungi masyarakat dari paraktek-praktek yang tidak kompeten, sehingga merusak citra pendidik dan tenaga kependidikan, 3) membantu dan melindungi lembaga penyelenggara pendidikan, dengan menyediakan rambu-rambu dan instrument untuk melakukan seleksi terhadap pelamar yang kompeten, 3) membangun citra masyarakat terhadap profesi pendidik dan tenaga kependidikan, 5) memberikan solusi dalam rangka meningkatkan mutu pendidik dan tenaga kependidikan. ${ }^{5}$

Selain mempunyai tujuan, pelaksanaan sertifikasi guru juga mempunyai manfaat. Manfaat utama dari sertifikasi guru menurut Borang, yaitu 1) Melindungi profesi guru dari dari praktik-praktik merugikan citra profesi guru. 2) Melindungi masyarakat dari praktek pendidikan yang tidak berkualitas dan professional. 3) Meningkatkan kesejateraan ekonomi guru. Untuk memperoleh kulififikasi sebagai pendidik yang mempunyai sertifikasi tidaklah mudah, bayak hal yang harus ditempuh dan bekerja keras untuk menjadi pendidik yang bersertifikasi, karena sertifikat pendidik akan diperoleh guru apabila guru benar-benar mimiliki standar kompetensi dan profesional dalam

\footnotetext{
${ }^{5}$ Mulyasa. 34-35.
} 
profesinya, sehingga apabila guru yang telah mempunyai kualifikasi sertifikasi harus bisa mempertanggungjawabkan sertifikat yang deperoleh untuk memejukan kualitas pendidika serta dapat membuktikan kompetensi yang dimilikinya untuk mencapai sasaran pendidikan dan kualitas pendidikan yang lebih baik terutama dalam menjawab tantangan pendidikan di abad ke-21. ${ }^{6}$ Sehubungan dengan hal itu guru harus mampu mempersipkan diri untuk selalu belajar sepanjang hidup serta dituntut untuk selalu dinamis mengikuti perkembangan ilmu pengetahuan, teknologi, dan informasi.

\section{Peningkatan Profesionalisme Pendidik di Abad ke-21}

Peningkatan profesionalisme guru merupakan upaya untuk membantu guru yang belum memeiliki kualifikasi profesional menjadi profesional. Dengan demikian peningkatan kemampuan profesional guru merupakan bantuan atau memberikan kesempatan kepada guru tersebut melalui program dan kegiatan yang dialakukan oleh pemerintah. Menurut Glickman dalam Mulyasa guru profesional memiliki dua cirri yaitu tingkat kemampuan tinggi dan komitmen yang tinggi, oleh karena itu pembinaan profesionalisme guru harus diarahkan pada dua hal tersbut, apabila kedua nya beriringan akan membentuk pendidik yang profesional dalam menghadapi perkembangan pendidikan secara gelobal, baik dari krisis ekonomi, dan kebijakan yang berubah. Untuk kepentingan pendidik dapat melek kompetensi yang dapat enjamin mutu pendidikan perlu dilakukan peningkatan kompetensi dan profesionalisme guru sekarang dan masa yang akan datang. ${ }^{7}$

Menurut Borang, profesionalisme guru selain memiliki kualifikasi standar kompetensi dan sertifikasi guru yang profesional harus :1) Study Lanjut Program Stata 2, 2) kursus dan pelatihan, 3) pemanfaatan jurnal, 4) aktif dalam mengikuti seminar dan diklat pendidikan, 5) kerjasama antar lembaga profesi. ${ }^{8}$ Hal ini juga didukung hasil penelitian Aziz \& Akhtar "trained teachers are more competent than teachers having no training". 9 Sedangkan menurut Yulianti, standar kompetensi tidak cukup untuk menjadikan guru profesional dalam mengajar, akan tetapi diperlukannya pelatihanpelatihan yang mendukung profesi seperti workshop, penataran guru. membuat karya tulis ilmiah, dan diklat yang berkaitan dengan kemajuan pendidikan sekarang. Dengan demikian profesi guru tidak hanya sebagai suatu profesi saja, melainkan merupakan suatu seni untuk dapat mengkreasikan perangkat pembelajaran yang mendukung. ${ }^{10}$ Oleh karena itu, guru harus membangun dan mengembangkan dirinya, sehingga guru yang benarbenear profesional dapat melek kompetensi, melek sertifikasi dan melek tanggungjawab profesi yang di embannya dalam menghadapai perkembangan zaman dan tantangan global abad ke-21.

\section{Metode group investigation dalam proses pembelajaran menjawab tantangan pendidikan abad ke-21}

Seiring perkembangan globalisasi yang pesat, menuntut sumber daya manusia yang memiliki wawasan luas, keterampilan, kecakapan, pemikiran yang kritis dan terbuka. Pendidikan mengemban peran penting dalam hal ini, oleh karenanya pakar pendidikan

\footnotetext{
${ }^{6}$ Deitje. S. Borang, "Seminar Internasional APTEKINDO,” 2011. 247.

${ }^{7}$ Mulyasa, Standar Kompetensi dan Sertifikasi Guru. 13.

${ }^{8}$ Borang, "Seminar Internasional APTEKINDO." 248.

9 F. Aziz, Akhtar, dan M.S. Mahar, "Impact of Training on Teachers Competencies at Higher Education Level in Pakistan," International Refereed Research Journal 5, no. 1 (2014). 125.

${ }^{10}$ Rika Yulianti, "Peningkatan Kompetensi Guru Bahasa Inggris di SMP N 10 PADANG," Jurnal Administrasi Pendidikan 2, no. 1 (2014). 632-831.
} 
berusaha mengembangkan berbagai metode pembelajaran mutakhir, multimedia dan teknologi pembelajaran untuk pengalaman pembelajaran terbaik bagi perkembangan wawasan dan keterampilan peserta didik guna memenuhi tuntutan globalisasi. Sumber daya manusia berkualitas tidak terbentuk secara alamiah, butuh upaya untuk belajar dan pembiasaan. Karena menurut teori konstruktivis, pengetahuan akan terbangun di dalam pikiran peserta didik sendiri ketika ia berupaya mengorganisasikan pengalaman barunya berdasar pada kerangka kognitif yang sudah ada dalam pikirannya. ${ }^{11}$ Untuk mempersiapkan SDM berkualitas pendidikan tidak dapat berfokus pada kebutuhan material jangka pendek yang banyak dipraktekkan sekarang bahwa guru hanya memenuhi kebutuhan secara materiel yang hanya sekedar mentransfer ilmu untuk memenuhi ketuntasan di RPP, akan tetapi harus menyetuh dasar dengan memberikan watak dan mengembangkan berpikir untuk belajar bermakna yang sesuai visi dan misi pendidikan, yaitu perhatian mendalam pada etika moral dan sepiritual yang luhur. Untuk mencapai tujuan pendidikan nasional pemerintah telah menyelenggarakan perbaikanperbaikan peningkatan mutu pendidikan pada berbagai jenis jenjang, namun fakta di lapangan belum menunjukan hasil yang memuaskan. Dalam hal ini kualitas pendidikan dipengaruhi oleh penyempurnaan sistemik terhadap seluruh komponen pendidikan seperti peningkatan kualitas guru, kurikulum yang disempurnakan, perangkat pembelajaran, bahan ajar sarana dan prasarana yang memadai, iklim pembelajaran yang kondusif, serta didukung oleh kebijakan pemerintah baik pusat maupun daerah. Dari semuanya itu, guru merupakan komponen terpenting dalam membuat kualitas pendidikan yang efektif dan baik karena di tangan gurulah kurikulum, bahan ajar, sarana, dan prasarana, iklim pembelajaran menjadi sesuatu yang berarti bagi siswa untuk membangun karakter dan potensi yang ada didalam dirinya.

Keberhasilan proses pembelajaran dalam konteks teori belajar konstruktivis sangat bergantung pada keberhasilan interaksi multi arah atau student canter, interaksi yang dimaksud adalah interaksi edukasi dari (guru, lingkungan dan sosial media) yang berfungsi untuk mengembangkan berbagai potensi yang dimiliki peserta didik dalam rangka membangun pengetahuan dalam dirinya. Interaksi edukasi ini harus mampu membangun inspirasi, menyenangkan, menantang, memotivasi, serta memberikan ruang yang cukup bagi prakarsa, kreativitas dan kemandirian sesuai bakat, minat dan perkembangan fisik serta psikologis peserta didik. ${ }^{12}$ Era konstruktivis menempatkan peserta didik sebagai subjek belajar utuh yang diberikan ruang untuk mengekspresikan keinginannya untuk belajar sedangkan guru memberikan motivasi dan memfasilitasi, guru profesional dituntut mampu memahami setiap karakter peserta didiknya. Sejalan dengan upaya di atas, teori yang mendasari perubahan pradigma di dalam proses pembelajaran adalah teori konstruktivisme dari pengajaran John Dewey, dimana proses belajar terjadi dari pentingnya makna bekerja yaitu suatu proses berpikir aktif, hati-hati, yang melandasi proses berpikir kearah mengambil kesimpulan dari defenitif yang diperolehnya, bahwa siswa bergerak bolak-balik, antara masalah dan hipotesis ke arah pembuktian, sehingga sampai pada arah kesimpulan dalam batas-batas aturan yang bervareasi, namun peserta didik juga harus berperan aktif membangun sendiri pengetahuan di dalam memorinya karena dari proses discovery memberikan pengalaman, dan pengalaman memimpin orang berpikir sehingga dapat bertindak bijaksana dan baik. Namun, sangat tidak mungkin bagi guru untuk memberikan pelayanan yang khusus bagi 2008). 201.

${ }^{11}$ B.R. Hergenhahn, Olson, dan Matthew H., Theori of Learning (Jakarta: Prenada Media Group,

12 Yunus Abidin, Desain Sistem Pembelajaran dalam Konteks Kurikulum 2013 (Bandung: Refika Adimata, 2013). 2.

Al Amin: Jurnal Kajian Ilmu dan Budaya Islam, Volume 2, No 1, 2019|99 
setiap peserta didiknya dengan potensi dan model belajar yang beragam. Cara terbaik yang dapat dilakukan guru yaitu dengan menggunakan metode-metode mengajar yang bervariasi yang diharapkan dapat menyentuh potensi setiap peserta didik. Sehingga pemilihan metode yang dipilih harus memberikan kesempatan yang sama bagi setiap siswa dengan kperbedaan potensi dan gaya belajar yang berbeda. Metode group infestigasi merupakan sebuah pendekatan pembelajaran yang menempatkan peserta didik untuk mengedepankan rasa ingin tahunya, mengasah potensi kognitifnya dengan cara menyelidik, mencari dan membangun pengetahuannya sendiri dengan bantuan dan pengawasan guru.

Kuhlthau $(2010 ; 18)$ mengemukakan bahwa pendidik harus mencari jalan keluar yang baik untuk mempersiapkan peserta didiknya agar dapat hidup dan bekerja dalam era perubahan lingkungan informasi abad 21, "Educators around the world are seeking ways to prepare students for living and working in the changing information environment of the $21^{\text {st }}$ century. Sehingga untuk menjawab tantangan pendidikan di era abad ke-21 disinilah peran pendidik sangat penting terutama guru sebagai sektor pertama yang teribat langsung, berinteraksi dengan perekembangan potensi setiap individu, dan membuktikan profesionalisme yang dimilki untuk seperti dari hasil kualifikasi kompetensi dan bukti sertifikasi yang telah diberikan, karena pada hakeknya setiap individu memiliki potensi dan rasa ingintahu yang berbeda-beda, rasa ingin tahu setiap individu tidak terarah salah satu metode yang tepat dalam menyelesaikan permasalahan tersebut menggunakan metode group investigantion dimana dengan penggunaan group investigation di dalam proses belajar siswa dapat membangun pola berpikir kognitif di dalam memperoleh pengalaman belajar, sehingga belajar bukan lagi berpusat pada guru melainkan belajar terjadi dari banyak arah atau timbaal balik interaksi guru dengan siswa yang mungkin terjadinya aktivitas dan kreativitas yang diharapkan siswa terlibat langsung di dalam proses pemecahan masalah sehingga diperlukan keterampilan siswa dalam mengkomunikasikan dan proses kelompok belajar yang baik, sehingga pebelajaran menjadi bermakana dan (student canter). Johnson (2000) dalam Tanui dan Kiboss bahwa group investigation adalah Metode di mana kelompok mengambil tugas pada topik dalam unit yang dipelajari oleh seluruh kelas dan kemudian membagi setiap topik dalam tugas yang didistribusikan di antara anggota kelompok dan masing-masing murid menyelidiki subtopik nya secara individual dan akhirnya menyajikan temuan untuk keseluruhan kelas. $^{13}$

Group invertigation memerikan peranan sentral kepada siswa diberi kontrol dan pilihan penuh untuk merencanakn apa yang ingin dipelajari dan diinvestigasi. (Knight \&Bohlmeyer, 1990) dalam Doimus dan Akcay (2012 :110) mengemukakan "The Group Investigation (GI) the class is divided into several groups that study in a different phase of a general issue, the study issue is then divided into working sections among the members of the groups and students pair up the information, arrangement, analysis, planning and integrate the data with the students in other groups. In this process, the teacher must be the leader of the class and ensure that students comprehend the explanations".

Group infestiation di dalam proses pembelajaran merupakan suatu metode CL langka yang memberikan kebebasan yang cukup kepada siswa berdasarkan kelompokkelompok kecilnya yang befokus pada investigasi suatu topic atau objek khusus, untuk memiliki kebebasan dalam memutuskan komposisi tim mereka, memberikan peran dan

${ }^{13}$ E. K. Tanui dan J. K. Kiboss, "Effectiveness of e-Learning Investigation Model on Students," International Journal of Education and Practice, 7, 4 (2013). 56.

$100 \mid$ Al Amin: Jurnal Kajian Ilmu dan Budaya Islam, Volume 2, No 1, 2019 
tanggung jawab mereka, membangun dan menghapus norma dan perilaku yang diinginkan, dan menetapkan tujuan mereka, oleh karena itu karakteristik lain yang membedakan dari metode ini adalah upaya untuk menghilangkan persaingan di antara peserta atau siswa. Berikut ini fase secara umum, serta sub-fase yang setidaknya harus dilalui peserta didik dalam proses pembelajaran group investigation :

Gambar 1 framework pembelajaran group investigation

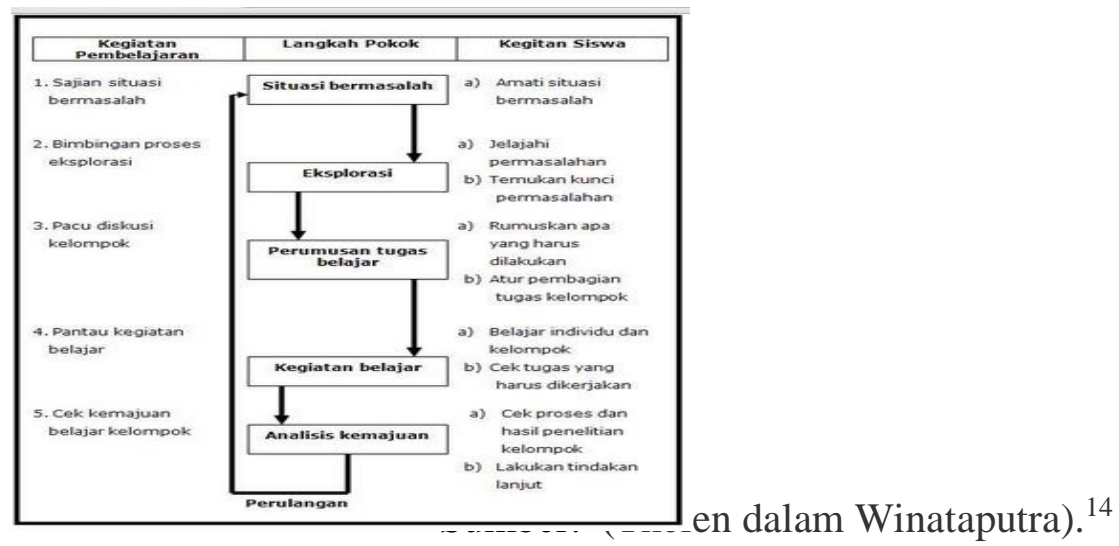

Tiap jenjang pendidikan menuntut kedalaman penguasaan materi dan keterampilan yang berbeda, tentunya metode group investigation dapat melatih siswa sebagai suatu ilmuan untuk mencari penyelesaian dengan hasil penemuan dan hipotesis yang telah ditentukan, dalam proses pembelajaran ini bisa digunakan untuk mengetahui pengetahuan siswa baik secar kelompok dengan membagi siswa secara heterogen maupun individu. Berdasarkan kerangka konseptul tersebut bahwa pembelajran dengan menggunakan group investigation sangat cocok digunakan didalam pembelajaran, karena dapat mendorong siswa untuk belajar dan menarik siswa untuk melakukan suatu penemuan dengan analsis, dan penelitian. Berdasarkan hasil temuan penelitian yang dilakukan oleh Tanui dan Kiboss dalam International Journal of Education and Practice Vol.4, No.7, 2013 yang berjudul Effectiveness of e-Learning Investigation Model on Students, bahwa hasil penelitian menunjukan efektifitas penggunaan group investigation didalam pembelajran yang dapat menimbulkan insteraksi siswa didalam belajar bermakna, selanjutnya dapat menumbuhkan strategi belajar siswa dengan mengembangakan pola berpikirnya dalam menemukan jawaban dari masalah yang dihadapi, menumbuhkan kolaboratif didalam belajar dimana siswa dapat saling berbagi pengetahuan yang diperoleh dan peneliti menyarankan bahwa penggunaan group

${ }^{14}$ Udin Winataputra S., Model-Model Pembelajaran Inovatif (Jakarta: Pusat: Direktorat Jenderal Pendidikan Tinggi Departemen Pendidikan Nasional, 2001). 37. 
investigation di dalam pembelajaran baik ilmu sosial maupun sains, dan dalam penerpannya harus meperhatikan lingkungan yang kondusip sehingga tercipta lingkungan belajar yang menarik dan efektif. ${ }^{15}$ Sedangkan berdasarkan penelitian Adora dalam International Journal of Humanities and Management Sciences (IJHMS) Vol : 2, Issue 3 (2014), yang berjudul "Group Investigation in Teaching Elementary Science", hasil penelitian dengan menggunakan pembelajaran cooperative dengan metode group investigation sangat efektif dibandingkan dengan pembelajaran dengan menggunakan metode konvensional, karena berdasarkan penelitian yang dilakukan bahwa group investigasi sebagai metode mengajar dapat dapat memeberikan kesempatan bagi siswa untuk bekerja sama sebagai tim terhadap pencapaian tujuan bersama, lebih lanjut dapat mengembangkan kepemimpinan dan keterampilan sosial dan memberikan kesempatan bagi siswa untuk bekerja dengan tanggungjawab masing-masing. ${ }^{16}$

Berdasarkan ulasan bebrapa peneliti di atas, tergambar bahwa pembelajaran group investigation sangat efektif untuk diterapkan dalam proses pembelajaran serta salah satu cara yang tepat dalam menghadapi tantangan pendidikan gelobal abad ke-21 dimana dapat menghasilakan pemudadan pemudi yang gemilang, komptitif, dan kreatif di dalam menghadapi perasalahan dan mencari solusi yang tepat. Dalam aplikasinya pembelajaran group investigation sangat menyeangkan bagi peserta didik didalam memahami kebermaknaan belajarnya karena peserta didik diberikan kesempatan menemukan ide dari hasil discovery dan pemaknaan sendiri terhadap materi yang dipelajarinya, meningkatkan kepercayaan diri siswa dalam berkomunikasi, bertanggung jawab dengan hasil yang diperolehnya. Pembelajaran group investigation diperlukan dalam pembelajaran baik pembelajaran sosial maupun sains dalam mengahdapi perkembangan gelobalisasi pendidikan di era abad ke-21. Selain itu metode pembelajarn ini sangat cocok digunakan karena memberikan pola berpikir siswa dengan mengatahui sendiri apa yang menjadi solusi yang tepat untuk menyelesaikan masalah yang dihadapi, menambah literasi peserta didik, meningkatkan kemampuan berpikir kritis dan kreatif menciptakan peluang serta membekalinya dengan keterampilan, menyiapkan peserta didik menjadi SDM yang unggul, siap menghadapi tantanagan gelobalisasi dan pendidikan abad ke-21.

\section{KESIMPULAN}

Kesiapan dalam mengadapi gelobalisasi dan perkembangan pendidikan di era abad ke-21merupakan tantangan terbesar dalam dunia pendidikan terutama guru sebagai pendidik di dalam meyiapkan SDM yang berkualitas, kompetitif dan kreatif. Disinalah peranan guru profesional yang sebagai agen perubahan yang paling dekat dengan siswa dalam memahami potensi dan gaya belajar di dalam proses pembelajaran berlangsung, selain itu guru yang profesioanl harus mampu membuktikan keprofesionalnya dengan melek akan kompetensi yang dimilik seperti memberikan bukti nyata dari 4 standar kompetensi yaitu : komptensi pedagogik, kepribadian, profesional, dan sosial, serta guru melek akan kulifikasi sertifikasi yang telah dimiliki dengan menujukan eksistensinya dalam memajukan pendidikan, karena pendidik yang telah tersertifikasi itu tidak menjadikan guru menjadi pribadi yang paling berkompeten, paling tahu, dan paling benar. Guru dituntut untuk selalu dinamis mengikuti perkembangan ilmu pengetahuan, teknologi, dan informasi. Sebagai pendidik, sudah seharusnya guru harus belajar seumur hidup (long life education). Oleh karena itu, guru harus membangun dan

15 Tanui dan Kiboss, "Effectiveness of e-Learning Investigation Model on Students."

${ }^{16}$ N. M. Adora, "Group Investigation in Teaching Elementary Science," International Journal of Humanities and Management Sciences (IJHMS) 2, no. 3 (2014).

102 |Al Amin: Jurnal Kajian Ilmu dan Budaya Islam, Volume 2, No 1, 2019 
mengembangkan dirinya, sehingga dia mampu mempertahankan kompetensi dan profesionalitas yang dimilikinya seperti aktif dalam kajian ilmiah seperti PTK, aktif dalam pelatihan dan diklat yang dapat menunjang profesionalitas guru dalam jabatanya dan profesinya, serta melakukan studi lanjut. Keseluruhan itu merupakan keharusan yang harus dimiliki oleh calon pendidik dan dilaksanakan oleh setiap guru yang profesional, karena kualifikasi professional tidak sebagai identitas belaka yang hanya digunakan untuk menaikan jabatan, akan tetapi harus ada pembuktian di dalam memajukan kualitas dan mencapai tujuan pendidikan seutuhnya. Selanjutnya pembuktian nyata yang harus dilakukan guru profesional antaralain menguasai berbagai metode dan media pembelajaran mutakhir, guna menyediakan pengalaman belajar terbaik bagi peserta didik serta menjadikan peserta didik aktif, kritis, kratif dan pembelajaran dapat bermakna yang menempatkan siswa sebagai subjek bukan lagi sebagai objek (student canter). Seorang guru profesional harus selalu berupaya meningkatakan kompetensi mengajarnya, Sebagai salah satu alternatif pembelajaran ilmu sosial khususnya ekonomi, metode group investigation sangat cocok diterapkan untuk materi-materi yang sulit, dan abstrak sekalipun baik di tingkat sekolah dasar, menengah dan tinggi. Dengan cara mengangkat topik aktual yang tejadi dalam kehidupan sehari-hari dapat membangkitkan rasa ingin tahu peserta didik, memahamkan materi ajar serta mengajak peserta didik berikir kritis, kreatif menghadapi permasalahan ekonomi dan mempersipakan peserta didik yang mampu bersaing dalam kemajuan pendidikan abad ke-21.

\section{DAFTAR PUSTAKA}

Abidin, Yunus. Desain Sistem Pembelajaran dalam Konteks Kurikulum 2013. Bandung: Refika Adimata, 2013.

Adora, N. M. "Group Investigation in Teaching Elementary Science." International Journal of Humanities and Management Sciences (IJHMS) 2, no. 3 (2014).

Aziz, F., Akhtar, dan M.S. Mahar. "Impact of Training on Teachers Competencies at Higher Education Level in Pakistan." International Refereed Research Journal 5, no. 1 (2014).

Borang, Deitje. S. "Seminar Internasional APTEKINDO,” 2011.

Hergenhahn, B.R., Olson, dan Matthew H. Theori of Learning. Jakarta: Prenada Media Group, 2008.

Inayah, dkk. "Pengaruh Kompetensi Guru, Motivasi Belajar Siswa, dan Fasilitas Belajar Terhadap Prestasi Belajar Mata Pelajaran Ekonomi pada Siswa Kelas XII IPS SMA Negeri 1 Lasem Jawa Tengah Tahun Pelajaran 2011/2012." Jurnal Pendidikan Insan Mandiri, 1, 1 (2013).

Mulyasa. Standar Kompetensi dan Sertifikasi Guru. Bandung: PT. Remaja Rosdakarya, 2013.

Tanui, E. K., dan J. K. Kiboss. "Effectiveness of e-Learning Investigation Model on Students." International Journal of Education and Practice, 7, 4 (2013).

Winataputra, Udin, S. Model-model Pembelajaran Inovatif. Jakarta: Pusat: Direktorat Jenderal Pendidikan Tinggi Departemen Pendidikan Nasional, 2001.

Yulianti, Rika. "Peningkatan Kompetensi Guru Bahasa Inggris di SMP N 10 PADANG." Jurnal Administrasi Pendidikan 2, no. 1 (2014). 
PENDIDIK HARUS MELEK KOMPETENSI DALAM MENGHADAPI PENDIDIKAN ABAD KE-21

104 |Al Amin: Jurnal Kajian Ilmu dan Budaya Islam, Volume 2, No 1, 2019 